\title{
The Internet and Film: Teaching Middle East Politics Interactively
}

\section{Soleiman M. Kiasatpour, University of California, Riverside}

$\mathrm{R}_{\mathrm{tc}}^{\mathrm{ec}}$ ecent innovations in information technology can benefit students and instructors if they are effectively integrated with the curriculum. As computer technologies have become more affordable, more powerful, and easier to use, their integration in education has increased. ${ }^{1}$ It is no longer unusual to find college courses that incorporate some online component. The most common way to use the Internet is to post an online version of the class syllabus with links to potentially more exciting sites. The Internet can, of course, be used interactively and in conjunction with other media to enhance the learning experience. ${ }^{2}$ One such medium is film.

This article describes a web-based instructional tool known as the "WWWBoard," or World Wide Web Board, ${ }^{3}$ and demonstrates its weaknesses and strengths through a recounting of its use by students taking a comparative class on the politics of the Middle East. Students in my class used WWWBoard to discuss and analyze films and videos they were required to watch as supplements to in-class lectures and presentations. The preliminary findings of a small survey of students who participated in this exercise are also presented. In addition, the views of instructors from the humanities and social sciences who have used discussion boards and discussion boards and film are provided.

Soleiman M. Kiasatpour received his Ph.D. from the department of political science at the University of California, Riverside in 1998. His dissertation is on regime transition in post-soviet Central Asia. He taught Middle East politics and international political economy at UCR and currently teaches at California State University, Dominguez Hills. An earlier version of this paper was presented at the 1998 meeting of the Western Political Science Association.

\section{The Web-Based Discussion Board: "WWWBoard"}

Its creator defines the web-based discussion board as follows:

WWWBoard is a threaded World Wide Web discussion forum and message board, which allows users to post messages, follow-up to existing ones and more.... WWWBoard ... comes with a WWWAdmin program which helps you maintain the WWWBoard. (Wright 1998)

A discussion board groups original messages and the responses to those messages in a descending "thread." The first entry is usually the "subject thread" and the follow-ups are listed in the order of their posting. Each entry is set off by a "bullet" and includes the subject heading, name of sender, time and date of posting, and the number of responses to that entry. By clicking onto the subject, one can view the sent message, read it, respond to the message, and become part of that "discussion." The discussion board includes many useful features. Messages can be sorted by date or thread. In addition, one can search the board for keywords that appear in the texts.

There are numerous ways that the WWWBoard can be used. First, it can be used simply as a discussion board on topics that the administrator, usually the instructor, decides to address. As such, it can be "free-flowing" or structured. The instructor has the option of guiding the discussions by posting questions and or calling students' attention to concepts and/or issues relevant to the class. Administrators can remove redundant messages, move single messages or whole threads around, and redirect discussion if necessary. Through the administrator's program, the instructor can bring up messages by name of author and/or by date. Thus, keeping the discussion on track is not difficult.
Second, the WWWBoard, like any other web-based program, can be linked to other sites and can include images (GIF and JPEG files). For example, it can be linked to the class syllabus and major news sources. Digital video clips can be incorporated, as can animated images. In short, the board can be a simple forum in which students share ideas, or it can be a full-fledged web site that includes links to other relevant and interesting sites.

\section{Using the WWWBoard and Film to Teach Middle East Politics}

I have used the discussion board as a forum for the critical analysis of film in my Politics of the Middle East class, a course geared to firsttime students of the region. The web site for the course, which includes the WWWBoard, is www.ucr.edu/ classes/posc152/wwwboard/ wwwboard.htm.

Teaching a course in comparative politics with a geographic area focus is challenging. Many students have not had adequate exposure to the political, social, economic, and geostrategic realities of regions other than own. I taught the class without the online assignment once before. At that time, I realized that too many readings of an interesting, yet widely misunderstood, region overwhelmed many of the students. Under the constraints of a quarter system, I had to present the only course on the Middle East that students were probably ever going to take as undergraduates. I was, therefore, obligated to present the material in an engaging manner that would not caricature the subject matter. Thus, I decreased the reading load, added the film and Internet component, and modified the testing methods. See Appendix 1 for a partial syllabus of the course.

Because there is insufficient time to 
TABLE 1

Results of Student Evaluations of Film and Web Assignment

\begin{tabular}{|c|c|c|c|c|c|}
\hline & $\begin{array}{l}\text { Strongly } \\
\text { Agree }\end{array}$ & Agree & Unsure & Disagree & $\begin{array}{l}\text { Strongly } \\
\text { Disagree }\end{array}$ \\
\hline \multicolumn{6}{|l|}{ Overall the film and web assignment } \\
\hline increased my interest in course material & $25 \%$ & $33 \%$ & 16 & $25 \%$ & - \\
\hline $\begin{array}{l}\text { increased understanding of concepts } \\
\text { important to Middle East Politics }\end{array}$ & 33 & 58 & - & 8 & - \\
\hline helped me to learn important skills & 42 & 25 & - & 33 & - \\
\hline encouraged me to work with others & 25 & 42 & - & 33 & - \\
\hline made the class more enjoyable & 33 & 8 & 42 & 16 & - \\
\hline made discussing issues than in class & 25 & 42 & 25 & 8 & - \\
\hline \multicolumn{6}{|l|}{$\begin{array}{l}\text { The film(s) prepared me for concepts } \\
\text { presented in class and/or texts }\end{array}$} \\
\hline $\begin{array}{l}\text { I would recommend this method for other } \\
\text { courses }\end{array}$ & 33 & 50 & 16 & - & - \\
\hline
\end{tabular}

Please feel free to comment on

1) the strengths of the film and web assignment*

enhances Internet and computer skills, new way of learning, wide variety of interests, seeing film in group led to immediate exchange, lets user focus on own interest, expansive learning, leads to greater interaction

2) the weakness of the film and web assignment availability problematic, Internet unnecessary (since we were in class together), people let others do the work, not all participated, should be voluntary

3) your overall opinion of the film and web assignment

fun, interesting, groups could focus, share information, challenging and enjoyable, do it again, "the class I remember the most," very good, excellent as learning tool

*Responses in descending order of frequency

cover the background of the entire Middle East in class, and because students tend to gloss over the critical historical, geographical, and cultural factors of the countries of the region given in the readings, I require students to watch a selection of films and videos. Film is both visual and aural. Thus, it can facilitate learning more effectively than solely visual or aural media. Ostrom (1998) argued that people learn more and retain more when lecture and film or visual demonstrations are combined rather than when lecture or film alone is used. ${ }^{4}$ Films have the added advantage of being available to students outside of class. Finally, because most images that students have of the Middle East have emanated from video imagery on television and/or in cinema, it is logical that some instruction be provided to the students via the same medium.

The Middle East is a region that has continuously been in the news the past two decades. Although mainstream TV and radio cover the region, the information provided is superficial at best. Often, the coverage is highly sensationalized. As a result, students come to my class with a weak understanding of the realities of the region. The consistently disappointing results of a map test and general information quiz I give to students at the beginning of the course demonstrate their lack of familiarity with basic terms and concepts. Many misconceptions that have been perpetuated by the media dominate student thinking. To address these inadequacies, I have compiled a set of noncommercial and independently produced films. See Appendix 2 for a partial listing of the films from which students chose. These films address the geography, history, and sociopolitical background of the Middle East. Some are interviews with leading Middle East scholars, while others are documentaries that focus on religion and culture, political conflict, and history. Acquiring the films can be tedious. Fortunately, many films are available through the interlibrary loan services of most universities and colleges. I also was able to purchase some from educational film companies. ${ }^{5}$

\section{The Exercise: Group Film Analysis and Online Discussion}

The main purpose of the exercise was to familiarize students with alternative representations of the Middle East, provide historical and geographical data, and highlight key factors affecting the politics of the region through critical group analysis of film. Students were asked to follow the instructions below:

1. Look over the film list

2. Choose one film to analyze

3. Find two (only two) other students willing to work with you (choose partners carefully)

4. Sign your names and write out your student IDs on the sheet that will be circulating; write out the email address of one member of the group who will be in charge of posting the original analysis (during the lengthy discussions, individual members of the group or outside the group can comment under the same thread and will be graded on their participation) 
5. Go to the Media Library; reserve the viewing room, or, if it is available right away, check out the film, view the film, and takc. notes

6. Divide components of analysis among your group members so that everyone does some writing

7. Do the analysis; write it out in essay form and proofread it

8. Go to www.ucr.edu/classes/ posc152/wwwboard/wwwboard. $\mathrm{htm}$; on the subject line, write the full title of the film and have the designated sender from \#4 above fill out the "Name" and "E-Mail" boxes; fill out the "Message" box with your analysis; click the "submit" button

9. Go back to the board often to view the other group's analysis of the same film

10. Follow up on their comments, criticisms, and suggestions within the appropriate thread

11. Make your own follow ups to their analysis or follow up their follow ups; and make sure you include your name and email address with each post

In essence, the exercise had two parts-film analysis and debate. The first required students to work together and write a summary of the film in essay form. In their analysis, students were asked to focus on their chosen film's statement of thesis, functions, effects, and/or meanings, on how the film supported its thesis, and on the broader implications of the film's content. In particular, students had to specify what questions, general and specific, about the Middle East the film answered or left unanswered.

Here, students had the opportunity to collectively utilize their critical thinking, analytical writing, and organizational skills. And since the film analysis diverges from typical, one-time, and static mini-term paper assignments, in which writing is done individually and read solely by the instructor, the final product seems to be more focused and better thought out.

The second part of the exercise required that each pair of groups submit their analyses of the film to the discussion board. Students were then encouraged to address their cohorts' critiques and engage in debate. Students were advised to address the factual and logical inconsistencies of the messages and asked not to engage in normative debates. This segment provided the students the chance to review, revise, and resubmit their work in light of their peers' comments. Since students received credit for both their group work and individual contributions, at this point of the assignment, a variety of views were proffered, which stimulated the debates.

\section{Advantages and Disadvantages}

The advantages of this exercise are numerous. First, the WWWBoard allows students to engage in free-flowing debate, whether they are on campus or at home. Students who might feel apprehensive about talking in class can participate and contribute readily on the board. Second, generally, it saves precious class time by allocating a significant portion of discussion to the web. Third, it allows the instructor to think out responses to student contributions. Common questions can be identified quickly and addressed effectively. Fourth, it gives students the opportunity to improve their research skills by familiarizing them with the World Wide Web. Finally, typing and reading posts enhances students' debating skills.

There are also some drawbacks to this method. Some students complained about access to computers with Internet connections. Another problem was participation by outsiders. To prevent the rare intrusion, if necessary, the administrator can activate a password program so only certain users can log on. Also, students should be reminded to identify themselves and take responsibility for their contributions. Outside participation is not necessarily bad. Several outsiders happened to "surf" in on the debates. Some made meaningful and passionate contributions. Unfortunately, others posted messages that contained profanity. Thus, on an academic WWWBoard, if outside participants are allowed to join the debate, some screening of submissions may be needed.

To assess the effectiveness of the WWWBoard and film assignment, questionnaires were sent to students who took the course. The students responded to eight items and also gave answers to open-ended questions. The questionnaire results appear in Table 1.

The last three questions offered students the opportunity to list the advantages and disadvantages of the exercise and to give their general opinions. With regard to the Internet component, the main concern was the availability of the resources. Another criticism was that the assignment was not voluntary. There were also complaints about free riding.

\section{Interpretation of the Survey Results}

Eighty percent or more of the students agreed or strongly agreed that the film and WWWBoard assignment increased their understanding of concepts, prepared them for class, and that this method be employed in other classes. Students were not quite sure whether the exercise made class more enjoyable. This mixed reaction may be due to the fact that students had to set aside time to meet with members of their group to view the film and subsequently discuss and post their analysis. This may have been an inconvenience for some. Also, it seems that some students like to work independently. That is why I advised students to, first, present a group analysis of the film then individually discuss the other group's analysis and individual submissions. Some students had apparently thought the follow-ups were to be done as a group.

The post-course survey results, on their own, do not demonstrate the qualitative differences in student participation and performance this exercise brought about compared with what students would have done if I had only assigned the traditional term paper, book report, thought paper, or other written work. The exchanges about Dreaming a Nation: The Kurds, for example, illustrate the high level of discussion that was generated using this approach. 


\section{A Sample Discussion}

The first group of three students (hereafter Group A) which analyzed Dreaming a Nation argued that the film's thesis was that the Kurds strong desire for nationhood was not enough to gain them autonomy. Strong internal divisions, collusion, intervention by neighboring states (Iran, Turkey, Iraq, and Syria), and geography were cited as major obstacles. Students offered insightful comparisons with the Japanese occupation of China, and asked, "Why can't the Kurds unite like the Chinese did and forget their ideological differences?" They suggested that perhaps the West is biased against certain nations and does not offer enough support.

The first individual response by a member of the second group which watched this film (hereafter Student 1B) praised Group A's work and reminded them of the importance of geography. She recalled the saying that "the only friends of the Kurds are the mountains." She also believed that the West would be more supportive if the Kurds were able to set aside their own differences.

The second individual (student 2B) replied that Western support was not enough. He stressed the fact that the approximately 20 million Kurds are spread across three nation-states, the topography prevents union, and that ideological differences between Marxist-Leninist Kurds and liberal-democrat Kurds are too great to be overcome. $\mathrm{He}$ also made an interesting argument that since the U.S. controlled the "No-Fly-Zone" in northern Iraq and Turkey, and consequently, the food routes, the Kurds were constantly vulnerable to outside powers (even "friendly" ones).

In a follow up, a member of Group A (hereafter student $1 \mathrm{~A}$ ) agreed with many of the comments but argued that "form of government is not key" and that the Kurds have not agreed upon the notion of nation-state or national identity. Many have become too assimilated in the states where they currently reside. Thus, to be unified, the Kurds need an identity they can agree upon.

Student $1 \mathrm{~B}$ replied to this post by arguing that ideology is not trivial and that form of government is important. Ideas are powerful and they motivate peoples to unite.

Yes, agreed student 1A, "Ideology can unify, but in this case it is dividing and wasting resources and efforts. Kurds need a nation before a party ID."

This sample discussion can be better appreciated by reading it on the actual WWWBoard in its entirety (by clicking on "Dreaming a Nation" on the course's WWWBoard site). The debate continued with the second group's analysis and individual contributions. Conclusions drawn included: the geopolitics and geography of the region will ultimately prevent formation of an independent Kurdistan since outside powers are unwilling to create instability in an already volatile region; a comparison with the establishment of the state of Israel may shed light on the reasoning behind international support, or lack thereof; and the main problem is that the Kurds have poor communication because of the mountainous terrain they live in and, thus, have no "physical unity" and no real sense of national identity. If they could "escape their physical boundaries," wrote student $1 \mathrm{~B}$, "they can unite."

Two outsiders from cyberspace participated in the discussion. The first was a "concerned U.S. citizen" who wanted to know how he could help. The second recounted a history of broken promises and treason by neighbors and "supporters" of the Kurds. The Shah of Iran backed the Iraqi Kurds in their 1974-75 war against the Iraqi government, but withdrew his support when he signed the 1975 Algiers treaty on cessation of hostilities over the Shatt al-Arab waterway between Iran and Iraq with then-vice president Saddam Hussein. The Kurdish resistance was crushed. History repeated itself, according to this contributor, when during the
1980-88 Iran-Iraq War, Iraqis used chemical weapons in the village of Halabcheh and killed off its population of "traitorous Kurds."

These exchanges on the WWWBoard about a one-hour film demonstrate the effectiveness of combining media for instructional purposes. The quality of the debate is much greater than it would have been in an impromptu class discussion. The frequency and flexibility of participation allowed for a thorough and meaningful exchange of ideas. I would like to emphasize that the comments reproduced above were almost completely the students' and not a regurgitation of the film's con-

tent. In addition, the participation of interested and passionate contributors from outside the class, in this case, actually enhanced the discussions.

Another important result of using WWWBoard was that students with "in-country" experiences in the Middle East were able to contribute more effectively and comfortably. Several Muslim women, who were reluctant to offer their experience regarding hijab (modest clothing and head covering) and the status of women in Islam in the classroom itself, gave the debate a "real world" dimension by sharing their views online. Also, some students were more comfortable writing their comments rather than saying them in class and these students were given the opportunity to contribute to the class.

\section{Other Instructors' Experiences}

The WWWBoard has been used by others at UC-Riverside. A Russian history instructor utilized it to generate discussion about lecture topics. The instructor has told me that the two most important advantages of the discussion board are that it allows shy 
students to participate and it provides an additional segment of time for class material to be discussed and understood. The same professor named the only major drawback as the problem of maintaining confidentiality. The instructor complained that anyone can log on to the board. Outsiders can get on the board and "hijack" the discussion. "Free riders have not paid the university fees that enrolled students have paid, yet are benefiting from the discussion." Password programs may deter unwanted "intruders," but create new problems such as students forgetting their passwords. ${ }^{6}$ Another related problem is that the comments an instructor posts to provoke discussion become public and can be misinterpreted.

This instructor dismissed the most common complaint students have about using the WWWBoard-lack of access to Internet connected computers-as an excuse used by unorganized students. If a student does not have access from home, the campus has several locations where a student can find a terminal at different times of the day to post his or her message. The amount of time that a student has to be online can be greatly reduced by uploading text from a disk.

Another instructor at UCR utilized the WWWBoard in an English class on gender and ethnicity. Students were asked to comment on the readings and the films that were assigned. The format was informal and nonstructured. Two groups were formed and took turns posting and responding, with responsibilities alternating each week.

In response to the question, "What do you think the advantages of using the board are?" This instructor named two. First, as far as students are concerned, "Those who don't talk in class feel free to talk on the board. Students get to know one another outside of class and can identify each other in class. They help answer each other's questions." Second, for the instructor, "I can answer more questions than I can in class by selecting comments to respond to. I also get to know students better." As for the disadvantages, the instructor believed that the board demands more time and work from the teacher and students than would a traditional in-class discussion.

\section{Conclusion}

The WWWBoard can be effectiely sed to teach political science. It is simple to set up and operate. The board allows students to contribute to discussions at their own convenience. Thoughts can be developed into meaningful written pieces and posted instantaneously to the board. The instructor can guide discussion and shift attention to new issues when needed. Links to valuable aca- demic resources can be included or added on the board at different segments of the discussion. Thus, students can refer to authoritative sources, learn valuable research skills, and hone their writing and debating skills. In addition, by integrating the discussion board with other activities, the instructor can further enhance the course.

Film analysis can be successfully incorporated in a discussion board assignment. Film provides students with information visually and aurally. And when the viewing is based on a focused and structured analysis, which will be evaluated both by the students' peers and instructor, and followed up with commentary and restatements, the results are pedagogically effective and surprisingly stimulating. While there are some drawbacks, such as accessibility and problems associated with small group work, these will and can be alleviated over time when Internet connections become even more inexpensive and abundant and through a combination of individual and group activities that are clearly delineated for the students. As information technology advances, instructors and students alike must be able to work together to get the most out of these innovations and incorporate them in and outside of the classroom to improve the learning experience.

\section{Notes}

\begin{abstract}
1. "The Teacher" in the December 1995 issue of PS contained a series of articles detailing the use of the Internet for teaching political science. Authors described utilizing USENET discussion groups for class exercises, encouraging online discussion between students and the authors of course readings, using International Communication and Negotiation Simulations (ICONS) and gophers and email to role play international negotiations, and accessing White House briefings via the net.

2. Browning (1997) gives an extensive description of the application of Internet programs and digital video in a political science
\end{abstract}

laboratory. Browning's course incorporates CSPAN footage that is available through the Public Affairs Video Archives at Purdue University. Luna and McKenzie (1997) surveyed computer software, video disc, CD-ROM, and online sources on political science.

3. "WWWBoard" was created by Matthew

Wright and is available for free at www. wwwboard.com.

4. Ostrom compared three instructional methods-lecture, demonstration only, and lecture and demonstration. He found that the subjects' recall of material after three days for the three methods was 10,20 , and $65 \%$, re- spectively. He quotes Nobel Laureate Roger Sperry $(1993,2)$ who argued that "the learning curve rises dramatically when information is given simultaneously to both sides of the brain."

5. Films for the Humanities and Sciences, Inc. is one such company. I was able to get the generous support of the visual arts director for UC-Riverside's English department for purchasing these somewhat expensive videos.

6. This problem can be easily solved by having a single password for all students in the class.

\section{References}

Browning, Robert X. 1997. "Teaching American Government Interactively." Presented at the Annual Meeting of the American Political Science Association, Washington, DC.

Luna, Carl J., and Joe Mac McKenzie. 1997. "Beyond the Chalkboard: Multimedia

Sources for Instructors in Political Sci- ence." PS: Political Science and Politics. 30(March): $60-68$.

Ostrom, Richard. 1998. "Using Feature Films in Political Science Courses: Some Efficient and Effective Strategies." Presented at the annual meeting of the Western Political Science Association, Los Angeles.
Sperry, Roger W. 1993. Nobel Lecture. In Nobel Lectures in Physiology or Medicine 1951-1990, ed. Jan Lindsen. River Edge, NJ: World Scinetific.

Wright, Matthew. 1998. WWWBoard v3.00 $<$ www.wwwboard.com>. November 3 , 1998. 


\section{Appendix 1 Partial Syllabus for Politics of the Middle East}

The following are the requirements and texts.

\section{Requirements:}

Take-home mid-term examination \#1 = 20\%

Take-home mid-term examination \#2 $=20 \%$

Online discussion of several films to be viewed either in class or the Media Library $=20 \%$ (list of films and viewing times TBA)

In-class comprehensive final $=40 \%$

Texts:

Bill, James A., and Robert Springborg. 1994. Politics in the Middle East. 4th Ed. New York: Harper Collins.

Spencer, William. 1996. Global Studies: The Middle East. 6th Ed. Guilford, CT: Dushkin Publishing Group.

Lewis, Bernard. 1994. The Shaping of the Modern Middle East. New York: Oxford University Press.

Esposito, John L. 1996. The Islamic Threat: Myth or Reality? 2nd ed. New York: Oxford University Press.

The Reader (available at Printing \& Reprographics) a series of journal and newsmagazine articles.

Optional texts:

Laqueur, Walter, and Barry Rubin, eds. 1995. The IsraelArab Reader: A Documentary History of the Middle East Conflict. 5th Ed. New York: Penguin Books.

Said, Edward W. 1994. Orientalism. New York: Vintage Books.

Schimmel, Annemarie. 1991. Islam: An Introduction. Ithaca: Cornell University Press.

\section{Appendix 2 Partial List of Films Used in Politics of the Middle East*}

Living Islam: The Last Crusade, Vol. 6. 1993. Ambrose Video Publishing, Inc. New York, and BBC Enterprises, Ltd.

Chronicles the rise of political Islam in Nigeria. Looks at the role of Islam in Bosnia, what Jerusalem means to Muslims, and why Hebron is significant. Focuses on jihad, the crusades, Muslim reaction to the West, and reasons for the Islamic world's "anti-Western" positions.

The Arab World: Arabs and the West, Part 5. 1991. A Bill Moyers Production.

An interview with Charles Issawi, an Egyptian, reviews the relationship between the Arab world and the West, the results of modernization, what Muslims want from the West, and what the future holds.

Islam and War. 1994. Films for the Humanities and Sciences, Inc.

An interview with Seyyed Fadlallah, a leading Islamic cleric among Lebanese Shia and spiritual leader of Hezbol lah. Questions Fadlallah on the role of jihad in Islam, the use of violence against Israel, the West, and civilians. Fadlallah discusses the role of defensive and offensive war according to Islam.

Living Islam: Foundations, Vol. 1. 1993. Ambrose Video Publishing, Inc., New York, and BBC Enterprises, Ltd. Reviews the spiritual aspects of Islam. Documents the conversion of pagans in Mali by a living Muslim "saint." De- scribes the role of Islam in France. Covers the hajj and the significance of the Quran. Looks at the place of Jerusalem and Islam in Central Asia from an anthropological perspective.

The Arab World: Image of God, Part 3. 1991. A Bill Moyers Production.

An interview with three Arab scholars who examine why Islam has been given a "bad name." Discussion of the pillars of Islam, role of the crusades, what "fundamentalists" want, and the relationship between the West and Islam.

Introduction to the End of an Argument. 1990. Joyce Salloum and Eli Suleiman.

Traces the genesis of stereotypical images of Arabs and the Middle East by mimicking mainstream TV, film, and news shows on Middle East politics.

Israel: The First Forty Years. 1993. Films for the Humanities and Sciences, Inc.

Retraces the tumultuous first forty years of the "oldest surviving democracy and newest nation" in the Middle East.

The Holocaust: Judgment in Jerusalem. 1990. BBC Production. Films for the Humanities and Sciences, Inc.

The 1961 trial of Adolf Eichmann serves as the centerpiece for an analysis of Hannah Arendt's work on the banality of evil and the legality of the trial. Casts light on Arendt and the Holocaust.

Dreaming a Nation: The Kurds. 1994. Films for the Humanities and Sciences, Inc.

A geographical and historical overview of the Kurds. Looks at the prospects for the formation of a unified "Kurdistan." Focuses on the relationship between the state and Kurds in Iraq, Iran, and Turkey.

This is Our Land: Fundamentalisms Observed. 1992. University of Chicago, BBC TV, and WETA TV. PBS video. The story of Gush Emunim, an Israeli settlers movement. Looks at the organization and its objectives. Covers the early history of settlements in Hebron and the occupied territories.

Remaking the World: Fundamentalisms Observed. 1992. University of Chicago, BBC TV, and WETA TV. PBS video.

Reviews the development of fundamentalism in Egypt. The Muslim Brotherhood and other groups that have gained popularity in recent Egyptian history are examined. The role these groups play in society and their relations with the outside world are addressed.

Struggling with Modernity. 1993. BBC TV.

Analyzes the roles of Islam, the state, and modernization.

Recording the Truth. 1984. South Productions for Channel 4.

The Iranian revolution, the Iran-Iraq War, hostages, and the media in Iran as seen by Iranian opponents of the Islamic Republic. A pictorial of the revolution and war with commentary by both supporters and opponents of the regime. In Farsi and Arabic with English subtitles.

The Islamic Mind with Seyyed Hossein Nasr. 1990. Films for the Humanities and Sciences, Inc.

Bill Moyers interviews Nasr on the roots of Islam's attitudes toward the West, the possibility of peace in the Middle East, and how Islam and the West can coexist. 
Appendix 2 continued

Women and Islam. 1994. Films for the Humanities and Sciences, Inc. Islamic Conversion Series.

An interview with Leila Ahmed, Professor of Women's Studies, University of Massachusetts, Amherst on the role of women in Islam. Outlines the rights and responsibilities of women according to Islam. Rejects common stereotypes.

Oasis of Peace. 1995. Jocelyn Ajami.

The story of a village in Israel where Jews and Palestinians live happily and on equal terms. Documents the village's "School for Peace," whose workshops have earned it five Nobel Peace Prize nominations.

Beyond the Veil: Are Iranian Women Rebelling? 1994. Films for the Humanities and Sciences, Inc.

A female reporter goes undercover to see how women in Iran deal with the hijab and official dress codes.

Palestine: 1890-1990. 1991. Films for the Humanities and Sciences, Inc.

An overview of the history of the Palestinian people with a particular focus on the rise of the PLO and the intifada.

Saddam's Killing Fields. 1992. Christopher Jeans. Films for the Humanities and Sciences, Inc.

\section{ht tp://www.hallway.org/journal}

\section{Announcing the \\ Electronic Hallway Journal}

7

he Electronic Hallway is pleased to offer The Electronic Hallway Journal-an online forum for peer reviewed cases in the field of public administration and policy.

\section{If you've recently written a case and are searching for a publication venue, now is the time to submit your work!}

\section{Look for our first edition on the Web in July 1999.}

The Electronic Hallway Journal is a product of the advice and support of faculty, deans, and directors across the country.

This journal is a branch of the Electronic Hallway Network, an Internet-based syllabus planning resource that allows you to download teaching materials instantly from the office, hotel room or any computer that accesses the Web.

Both the Electronic Hallway, and the new Hallway Journal, which are governed and edited by a sixuniversity consortium, are available to you thanks to the support of The Pew Charitable Trusts, an increasing number of supporting schools and departments, NASPAA and the Microsoft Corporation.

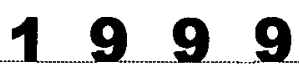

Online Journal Published..

Call for Submissions

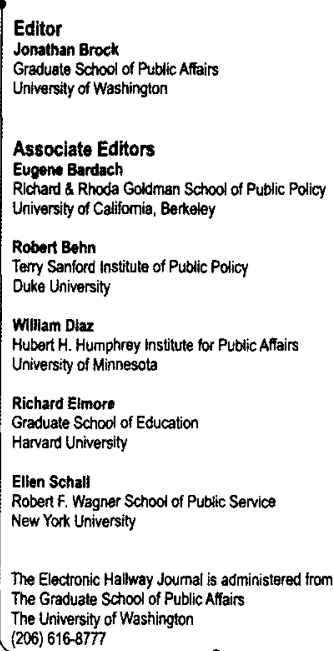

(206) 616-877 